\title{
Pengukuran Parameter Bahan Organik Di Perairan Sungai Silugonggo, Kecamatan Juwana, Kabupaten Pati
}

\author{
Erick Samuel Frederico Hasibuan*, Endang Supriyantini, Sunaryo \\ Departemen Ilmu Kelautan Fakultas Perikanan dan Ilmu Kelautan, Universitas Diponegoro \\ Jl. Prof. H. Soedarto S.H., Tembalang, Semarang, Jawa Tengah,50275 Indonesia \\ Email: ericksamuelhsb24@gmail.com
}

\begin{abstract}
Abstrak
Perairan Silugonggo merupakan area pemukiman warga dengan banyak aktivitas perikanan dan kelautan seperti: pertambakan, industri perikanan dan merupakan alur pelayaran. Tingginya aktivitas pemukiman dan industri akan menghasilkan limbah organik dalam jumlah besar. Bahan organik yang melimpah dapat menimbulkan pencemaran lingkungan. Penelitian ini bertujuan untuk mengetahui kandungan bahan organik di perairan sungai Silugonggo, Kecamatan Juwana, Kabupaten Pati. Kandungan bahan organik diketahui melalui analisis parameter TOM (Total Organic Matter), $\mathrm{BOD}_{5}$ (Biochemical Oxygen Demand) dan COD (Chemical Oxygen Demand). Pengambilan sampel dilaksanakan pada tanggal 20 Desember 2019 dan 20 Januari 2020. Metode yang digunakan pada penelitian ini menggunakan metode kasus dengan pengamatan secara langsung di lapangan dan penentuan lokasi penelitian menggunakan metode purposive sampling. Hasil pengukuran parameter penelitian dianalisis menggunakan analisis ragam. Hasil penelitian menunjukkan bahwa nilai TOM sebesar $8,11-11,9 \mathrm{mg} / \mathrm{L}$. Hasil pengukuran parameter (a) $\mathrm{BOD}_{5}$ sebesar 8,07 - 24,66 mg/L dan (b) COD sebesar 26,04 - 79,21 mg/L, hasil tersebut berada di bawah baku mutu yang ditetapkan menurut Keputusan Menteri Lingkungan Hidup No. 51 Tahun 2004 tentang Baku Mutu Air Limbah. Tingginya nilai TOM dikarenakan banyaknya masukan limbah bahan organik dari aktivitas di perairan sungai Silugonggo, seperti: pertambakan, industri perikanan, dan alur pelayaran.
\end{abstract}

Kata kunci : TOM, $\mathrm{BOD}_{5}, \mathrm{COD}$, Perairan Silugonggo

\section{Abstract \\ Measurements of Organic Matter in Waters of Silugonggo River, Juwana Region, Pati}

Silugonggo waters is a residential area with many fishery and marine activities such as: aquaculture, fishing industry and shipping lanes. High residential and industrial activities will produce large amounts of organic waste. Abundant organic matter can cause environmental pollution. This study aims to determine the content of organic matter in the waters of the Silugonggo River, Juwana District, Pati Regency. The content of organic matter is known through parameter analysis of TOM (Total Organic Matter), BOD5 (Biochemical Oxygen Demand) and COD (Chemical Oxygen Demand). Sampling was carried out on December 20, 2019 and January 20, 2020. The method used in this study used the method of direct observation in the field and the date of the research location using the purposive sampling method. The results of the measurement of research parameters were analyzed using analysis of variance. The results showed that the TOM value was $8.11-11.9 \mathrm{mg} / \mathrm{L}$. Parameter measurement results (a) BOD5 of 8.07-24.66 $\mathrm{mg} / \mathrm{L}$ and $(\mathrm{b}) \mathrm{COD}$ of $26.04-79.21 \mathrm{mg} / \mathrm{L}$, these results are below the quality standard stipulated according to the Decree of the Minister of the Environment No. 51 of 2004 concerning Wastewater Quality Standards. The high value of TOM is due to the large number of inputs of organic matter from activities in the waters of the Silugonggo river, such as: aquaculture, fishing industry, and shipping lanes.

Keywords : TOM, BOD, COD, Silugonggo River 


\section{PENDAHULUAN}

Sungai merupakan tempat mengalirnya air yang dimulai dari mata air sampai muara dengan dibatasi kanan dan kirinya sepanjang pengalirannya oleh garis sempadan (Peraturan Pemerintah Republik Indonesia No. 38 Tahun 2011). Sungai Silugonggo adalah sungai terbesar yang mengalir di Kecamatan Juwana, Kabupaten Pati, Jawa Tengah. Sungai ini memiliki nilai ekonomi yang tinggi. Hal tersebut, dikarenakan di sekitar aliran Sungai Silugonggo merupakan area pemukiman warga dengan banyak aktivitas perikanan dan kelautan, seperti: pertambakan, industri perikanan dan alur pelayaran TPI. Aktivitas masyarakat yang berlangsung di sekitar Sungai Silugonggo tersebut, berpotensi menyumbangkan sejumlah besar limbah bahan organik dalam jumlah besar. Sumber limbah bahan organik di sekitar Sungai Silugonggo dapat berasal dari limbah pemukiman penduduk yang dibuang ke sungai, limbah pertambakan yang merupakan hasil sisa pakan yang tidak termanfaatkan dan limbah-limbah dari aktivitas perikanan lainnya. Pemerintah Kabupaten Pati, menyebutkan bahwa jumlah air buangan yang dapat dibuang satu rumah adalah sebesar $1 \mathrm{~m}^{3}$. Dari satu rumah, dapat menyumbangkan $80 \%$ limbah perairan, yang terdiri dari: limbah cuci, limbah mandi dan limbah bekas makanan (Belladona dan Yanto, 2014). Limbah-limbah tersebut akan menyebabkan pengkayaan nutrien di perairan. Pengkayaan nutrien pada perairan ini terjadi melalui proses dekomposisi senyawasenyawa organik menjadi senyawa anorganik oleh organisme dekomposer (Supriyantini et al., 2017).

Kegiatan yang sebagaimana sudah disebutkan sebelumnya, dapat mempengaruhi peningkatan kandungan bahan organik di Sungai Silugonggo. Tingginya kandungan bahan organik akan mengganggu keadaan perairan dan jika kandungan bahan organik tersebut melebihi baku mutu, maka akan menimbulkan pencemaran lingkungan. Kandungan bahan organik mencerminkan kondisi kualitas perairan (Sari et al., 2014). Pentingnya mengelola kualitas perairan salah satunya untuk menjaga keseimbangan ekologis. Kandungan bahan organik yang berlebih akan menimbulkan pencemaran di perairan, berupa kondisi kesuburan yang terlalu tinggi. Kondisi subur yang berlebihan ini akan menyebabkan eutrofikasi atau tingginya kadar nutrien di perairan, sehingga terjadi ledakan populasi tumbuhan perairan tentunya hal ini akan mengganggu makhluk hidup ataupun biota yang berada di lokasi (Ismoyo et al., 2017).

Penelitian ini bertujuan untuk menganalisis kandungan bahan organik di Perairan Sungai Silugonggo, Kecamatan Juwana, Kabupaten Pati melalui pengukuran parameter TOM (Total Organic Matter) dan menentukan tingkat pencemaran bahan organik melalui pengukuran parameter $\mathrm{BOD}_{5}$ (Biochemical Oxygen Demand) dan COD (Chemical Oxygen Demand). Kemudian, hasil pengukuran parameter-parameter tersebut dibandingkan berdasarkan baku mutu yang ditentukan oleh pemerintah dalam Keputusan Menteri Lingkungan Hidup No. 51 Tahun 2004.

\section{MATERI DAN METODE}

Materi penelitian adalah sampel air permukaan yang diambil darimuara Sungai Silugonggo, Kecamatan Juwana, Kabupaten Pati. Sampel air diambil sebanyak dua kali yaitu tanggal 19 Desember 2019 dan 19 Januari 2020. Sampel air dianalisis di Laboratorium Teknik Lingkungan Universitas Diponegoro untuk mengetahui kandungan Alkalinitas, $\mathrm{BOD}_{5}$ (Biochemical Oxygen Demand), COD (Chemical Oxygen Demand), TSS (Total Suspended Solid), TDS (Total Dissolved Solid), TOM (Total Organic Matter), Nitrat, Nitrit dan Amonia. Beberapa data pendukung parameter kualitas perairan juga diambil secara in situ, meliputi: DO (Dissolved Oxygen), pH (Derajat Keasaman), suhu, salinitas, kecerahan, kedalaman dan kecepatan arus.

Metode penelitian yang digunakan adalah metode studi kasus, yaitu laporan informasi deskriptif dan analisis mendalam dari suatu sistem yang saling berkaitan (Merriam dan Tisdell, 2015). Metode ini dipilih berdasarkan pertimbangan di mana pada studi terdahulu oleh Aina et al. (2016), perairan ini menunjukkan kondisi perairan yang cukup tercemar. Penentuan lokasi penelitian dilakukan dengan menggunakan purposive sampling. Metode ini dipilih berdasarkan pertimbangan pada ciri atau sifat tertentu yang dipandang memiliki hubungan erat dengan ciri dan populasi (Hadi, 1993). Penentuan lokasi ditentukan berdasarkan pertimbangan letak lokasi dengan aktivitas yang menghasilkan buangan limbah organik terbanyak yang berada di Sungai Silugonggo (Gambar 1), yaitu meliputi: (a) 
Stasiun 1 : Pelabuhan kapal, TPI dan Pemukiman. Terletak pada koordinat $06^{\circ} 42^{\prime} 10.44^{\prime \prime}$ S sampai

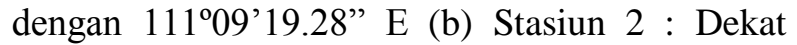
pertambakan. Terletak pada koordinat $06^{\circ} 41^{\prime} 05.96^{\prime \prime} \mathrm{S}$ sampai dengan $111^{\circ} 09^{\prime} 47.20^{\prime \prime} \mathrm{E}$ (c) Stasiun 3 : Muara sungai dekat ekosistem mangrove. Terletak pada koordinat $06^{\circ} 39^{\prime} 46.18^{\prime \prime}$ S sampai dengan $111^{\circ} 11^{\prime} 13.69^{\prime \prime} \mathrm{E}$

Pengambilan sampel air dilakukan di perairan Sungai Silugonggo sebanyak 2 kali dengan rentang waktu 1 bulan, yaitu: pada bulan Desember 2019 dan Januari 2020. Sampel air yang diambil adalah air permukaan dengan kedalaman \pm 1 meter (Kepmen LH No. 37 Tahun 2003). Sampel air diambil di masing-masing stasiun menggunakan botol Nansen dan disimpan pada botol gelap dengan volume 1,5 liter. Sampel air lalu dimasukkan ke dalam cool box untuk dianalisis kandungan bahan organiknya melalui analisis parameter-parameter, seperti: TOM, BOD, COD. Diamati pula parameter pendukung penelitian lainnya berupa parameter kimia, seperti: Amonia $\left(\mathrm{NH}_{3}\right)$, Nitrat $\left(\mathrm{NO}_{3}{ }^{-}\right)$, Nitrit $\left(\mathrm{NO}_{2}{ }^{-}\right.$ ), TSS, TDS dan alkalinitas serta parameter fisika adalah: suhu, salinitas, $\mathrm{pH}$, oksigen terlarut, kecerahan, kecepatan arus dan kedalaman. Pengumpulan data curah hujan dilakukan melalui data iklim BMKG Stasiun Klimatologi Semarang.

Data yang diperoleh berupa parameter bahan organik, diolah menggunakan aplikasi software SPSS 24. Data terlebih dahulu dianalisis normalitas, homogenitas dan additivitasnya. Selanjutnya dilakukan uji Two Way Anova untuk mengetahui perbedaan antar perlakuan (Aziza dan
Zahruddin, 2010). Jika terdapat perbedaan antar perlakuan, selanjutnya dilakukan uji lanjut untuk mengetahui letak perbedaan antar perlakuan satu dengan lainnya (Septiana dan Ardiaria, 2016). Variabel bebas yang digunakan dalam penelitian ini adalah berupa stasiun dan waktu pengambilan, sedangkan variabel terikat berupa parameter bahan organik.

Data penelitian yang diperoleh juga dianalisis secara deskriptif yang hasilnya diinterpretasikan melalui tabel dan grafik. Hasil data lapangan dibandingkan dengan baku mutu Keputusan Menteri Negara Lingkungan Hidup Nomor 51 Tahun 2004, Tentang Baku Mutu Air Laut untuk Biota Laut dan Keputusan Menteri Negara Kependudukan dan Lingkungan Hidup Nomor 2 Tahun 1988, Tentang Baku Mutu Air Limbah.

\section{HASIL DAN PEMBAHASAN}

Kandungan Bahan Organik di Perairan Silugonggo dapat diamati melalui besaran kandungan TOM (Total Organic Matter) yang dihasilkan. TOM (Total Organic Matter) merupakan seluruh bahan organik yang berasal dari detritus, fitoplankton atau hasil buangan biota lainnya yang diuraikan oleh mikroorganisme di sekitar perairan (Rustam et al., 2018). Kisaran kandungan TOM di perairan sungai Silugonggo pada bulan Desember 2019 adalah 8,22 - 11,9 $\mathrm{mg} / \mathrm{L}$ dengan rata-rata sebesar $11,23 \mathrm{mg} / \mathrm{L}$ dan kisaran TOM pada bulan Januari 2020 adalah sebesar 9,9 - 11,69 dengan rata-rata sebesar 9,48

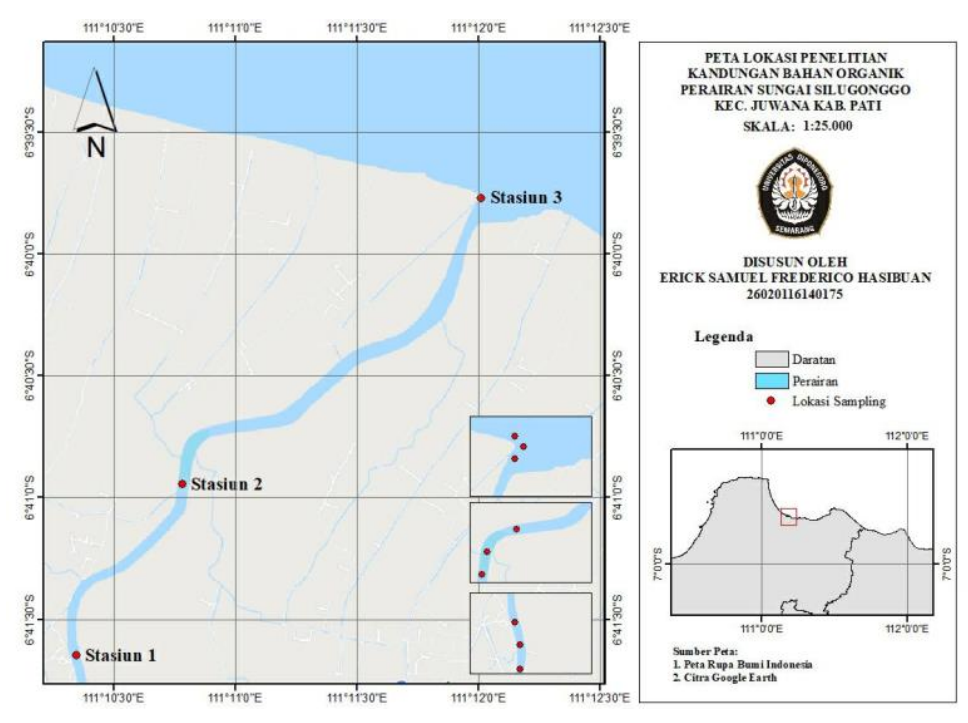

Gambar 1. Titik Sampling Lokasi Penelitian 
mg/L (Gambar 2). Kandungan TOM pada bulan Desember 2019 berbeda secara signifikan terhadap kandungan TOM pada bulan Januari $2020(\mathrm{p}<0,05)$.

Waktu pengambilan mempengaruhi kondisi arus di lokasi pengamatan. Kondisi arus berbeda pada waktu pengambilan mempengaruhi besar nilai TOM yang dihasilkan. Pada bulan Januari 2020, arus lebih kencang dibandingkan pada bulan Desember 2019 sehingga nilai TOM pada bulan Desember berbeda secara signifikan dengan hasil pada bulan Januari $2020(\mathrm{p}<0,05)$. Hal ini sesuai dengan hasil pengukuran kecepatan arus di lapangan pada bulan Januari lebih tinggi yaitu sebesar $0,33 \mathrm{~m} / \mathrm{s}$, sedangkan pada bulan Desember sebesar $0,07 \mathrm{~m} / \mathrm{s}$ (Tabel 1). Arus yang kencang akan membawa material organik menyebar ke arah laut secara lebih luas (Maslukah et al., 2014). Artinya, bahwa arus kencang dari aliran sungai akan membuat materi organik menyebar lebih luas sehingga nilai TOM pada bulan Januari 2020 lebih kecil.

Kandungan TOM di bulan Desember 2019, jumlahnya lebih tinggi dibandingkan dengan Januari 2020 (Gambar 2). Hal ini dikarenakan rata-rata suhu di bulan Januari lebih tinggi yaitu sebesar $32,92^{\circ} \mathrm{C}$ dibandingkan dengan suhu bulan Desember 2019 sebesar 32,330 C (Tabel 1). Suhu yang tinggi akan menghasilkan bahan organik rendah. Hal tersebut didukung oleh pendapat Atima (2015) di mana suhu yang tinggi akan membuat organisme pendegradasi sumber bahan organik kurang optimal dalam merombak senyawa yang menghasilkan bahan organik. Sehingga jumlah pengurai menjadi lebih sedikit dan bahan organik yang terurai pun semakin sedikit pada Bulan Januari 2020.
DO memiliki pengaruh terhadap besaran kandungan suatu bahan organik di perairan (Yuningsih et al., 2014). Hasil pengukuran DO pada bulan Januari lebih tinggi yaitu $4,3 \mathrm{mg} / \mathrm{L}$ dibandingkan pada bulan Desember yakni sebesar $2,5 \mathrm{mg} / \mathrm{L}$ (Tabel 1). Hal ini menandakan bahwa kebutuhan oksigen mikroorganisme pengurai dalam menguraikan bahan organik pada Bulan Desember cukup tinggi. Menurut Supriyantini et al. (2017) DO yang rendah disebabkan oleh tingginya kandungan bahan organik total. Rendahnya nilai DO di bulan Desember 2019 akan meningkatkan nilai Amonia, Nitrat dan Nitrit (Tabel 1) sehingga dapat diprediksi bahwa bakteri pendegradasi bahan organik pada bulan Desember melimpah jumlahnya. Jumlah bakteri pendegradasi yang melimpah mengindikasikan bahwa bahan organik yang diurai juga cukup tinggi. Turunnya DO akan mengurangi konsumsi oksigen beberapa organisme sehingga beberapa organisme akan mati dan terurai, kemudian uraian organisme yang mati ini akan menjadi partikel bahan organik mengeluarkan zat-zat seperti ammonia dan nitrit saat proses degradasinya berlangsung (Rahmawati et al., 2015).

Tingginya konsentrasi Aammonia, nitrit dan nitrat di perairan sebagian besar diduga berasal dari limbah pemukiman dan pembuangan manusia dan hewan dalam bentuk urin, di mana pemukiman penduduk sebagian besar berada di wilayah pesisir dan laut. Di sekitar perairan sungai Silugonggo, merupakan pemukiman nelayan dengan jumlah penduduk sekitar 87.484 jiwa (Profil Kabupaten Pati, 2015). Selain itu, secara alami senyawa ammonia di perairan juga dapat berasal dari hasil metabolisme hewan dan hasil proses dekomposisi bahan organik oleh

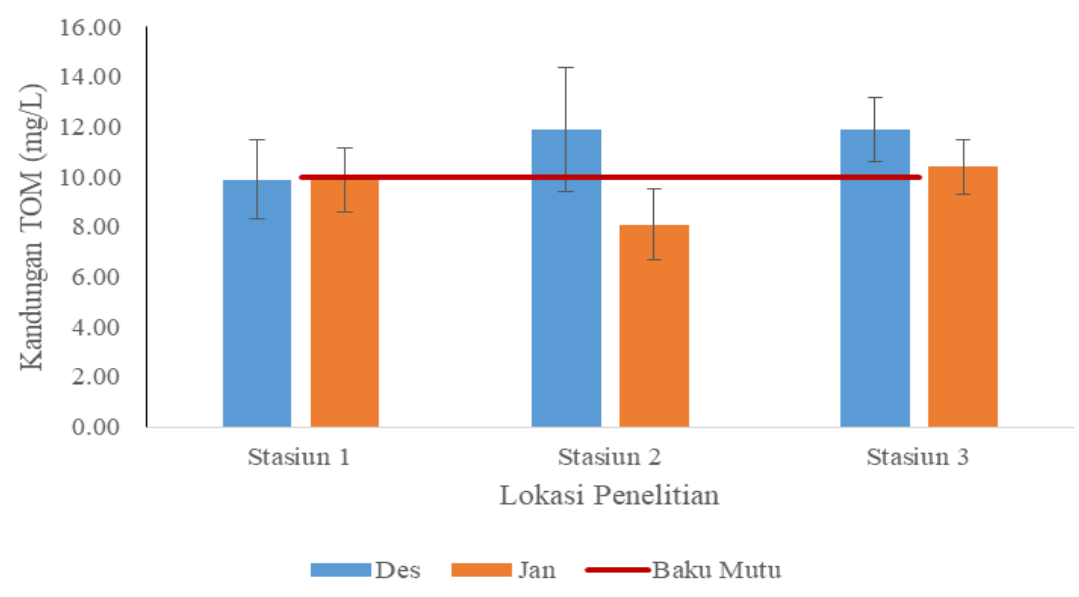

Gambar 2. Kandungan TOM di Sungai Silugonggo 
bakteri (Hamuna et al., 2018). Dari pernyataan tersebut, kenaikan nilai ammonia, nitrit dan nitrat tentu akan sejalan dengan naiknya proses dekomposisi bahan organik oleh bakteri dan senyawa pendegradasi bahan organik lainnya, yang artinya: pada bulan Desember 2019 terdapat banyak bahan organik yang dapat diurai menjadi ammonia, nitrit dan nitrat.

\section{Tingkat Pencemaran Bahan Organik}

Tingkat pencemaran bahan organik di perairan dapat diketahui dengan pengukuran parameter bahan organik berupa $\mathrm{BOD}_{5}$ dan COD. Biochemical Oxygen Demand atau kebutuhan oksigen biokimia menunjukkan oksigen terlarut yang dibutuhkan oleh organisme hidup untuk memecah atau mengoksidasi bahan-bahan buangan di dalam air. Jadi nilai BOD tidak menunjukkan jumlah bahan organik yang sebenarnya akan tetapi hanya mengukur secara relatif jumlah oksigen yang dibutuhkan untuk mengoksidasi bahan-bahan buangan tersebut (Rahmawati et al., 2015). Kandungan BOD di Sungai Silugonggo berkisar antara 8,07 - 24,66 $\mathrm{mg} / \mathrm{L}$ (Gambar 3). Tidak ada perbedaan nilai besaran $\mathrm{BOD}_{5}$ apabila ditinjau dari waktu pengambilan data. Dilihat dari baku mutu perairan, yaitu Keputusan Menteri Negara Lingkungan Hidup No 51 Tahun 2004 sebesar 50 $\mathrm{mg} / \mathrm{L}$, perairan Silugonggo memiliki kandungan BOD di bawah ambang batas baku mutu (Gambar 3).

Perairan Sungai Silugonggo belum dapat dikatakan tercemar apabila ditinjau dari parameter bahan organik BOD. Hal ini dikarenakan hasil pengukuran BOD belum melewati baku mutu perairan. Meskipun terdapat perbedaan nilai BOD secara signifikan $(\mathrm{p}<0,05)$ antara stasiun 1 dan 2 dengan stasiun 3, nilai BOD masih berada dalam ambang batas baku mutu perairan untuk limbah perairan (Gambar 3).

Kandungan bahan organik di Stasiun 3 sangat tinggi, hal tersebut dikarenakan oleh kondisi lingkungan di Stasiun 3 yang merupakan area vegetasi mangrove. Vegetasi mangrove dikenal akan banyaknya aktivitas makhluk hidup di dalamnya. Vegetasi mangrove menjadi tempat pemijahan dan feeding ground. Selain itu, vegetasi mangrove juga kaya akan aktivitas biologis di perairan (Supriyantini et al., 2017), sehingga bahan organik yang terurai menjadi $\mathrm{BOD}_{5}$ lebih tinggi dibandingkan dengan Stasiun 1 dan 2 yang merupakan areal pelabuhan serta tambak, di mana terdapat banyak buangankimiawi yang sulit diuraikan. Pada stasiun 1 dan 2 bahan pencemar didominasi oleh bahan dasar yang sulit diurai oleh mikroorganisme. Stasiun 1 dan 2 memiliki bahan buangan yang lebih dapat terurai dengan $\mathrm{COD}$ dibandingkan dengan $\mathrm{BOD}_{5}$ (Atima, 2015).

Bahan organik secara alamiah berasal dari perairan itu sendiri melalui proses - proses penguraian, pelapukan ataupun dekomposisi buangan limbah, baik limbah daratan, seperti: domestik, industri, pertanian dan limbah peternakan ataupun sisa pakan yang dengan adanya bakteri terurai menjadi zat hara (Suparjo, 2009). Zat-zat ini kemudian tersuspensi pada badan air yang menyebabkan kenaikan TSS (Rozali et al., 2016). Proses dekomposisi zat yang tersuspensi ini meningkatkan kandungan BOD

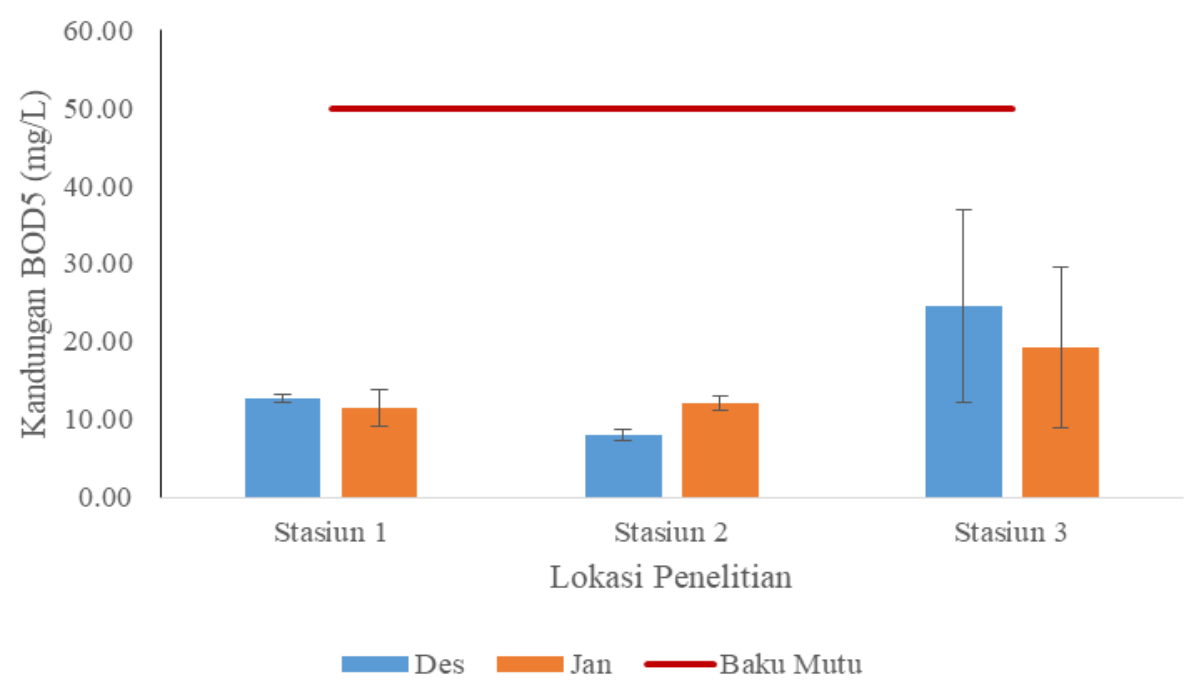

Gambar 3. Kandungan $\mathrm{BOD}_{5}$ di Sungai Silugonggo 
yang ada di perairan, seperti yang terjadi pada bulan Desember tercatat nilai TSS lebih tinggi yaitu $162,3 \mathrm{mg} / \mathrm{L}$ dibandingkan pada bulan Januari yaitu sebesar 83,67 mg/L (Tabel 1), sehingga dapat disimpulkan bahwa kenaikan TSS dapat menyebabkan kenaikan BOD. Besarnya nilai TDS juga mengindikasikan bahwa proses degradasi yang terjadi cukup besar dan jumlah BOD yang dihasilkanpun juga semakin tinggi (Paramita et al., 2012). Hal ini sesuai dengan hasil pengukuran di lapangan kandungan TDS yang tercatat pada bulan Desember lebih tinggi yaitu $5443,89 \mathrm{mg} / \mathrm{L}$ dibandingkan pada bulan Januari yaitu sebesar 910,44 $\mathrm{mg} / \mathrm{L}$, bahkan hasil pengukuran TDS di bulan Desember sudah melebihi baku mutu menurut (Keputusan Menteri Negara Lingkungan Hidup Nomor 51 Tahun 2004) yaitu sebesar $5000 \mathrm{mg} / \mathrm{L}$. Jika dilihat hasilnya nilai TDS yang paling tinggi berada di Stasiun 3 pada bulan Desember, hal ini dapat diartikan bahwa proses degradasi yang terjadi diduga paling banyak di stasiun tersebut. hal ini didukung oleh kondisi lokasi di stasiun 3 yang dekat muara dan banyak terdapat ekosistem mangrove. Proses degradasi yang tinggi di Stasiun 3 juga menyebabkan tingginya nilai $B O D$ di stasiun tersebut.

Nilai Kandungan COD di sungai Silugonggo berkisar antara 26,04-79,21 mg/L. Nilai masing-masing di setiap stasiun pada bulan Desember 2019, antara lain: 41,12 mg/L untuk stasiun 1; stasiun 2 sebesar 26,04 $\mathrm{mg} / \mathrm{L}$ dan stasiun 3 sebesar 79,21 mg/L. Pada bulan Januari
2020 nilai COD di setiap stasiun, adalah: 37,26 $\mathrm{mg} / \mathrm{L}$ untuk stasiun $1 ; 38,84 \mathrm{mg} / \mathrm{L}$ untuk stasiun 2 dan $62,17 \mathrm{mg} / \mathrm{L}$ untuk stasiun 3 (Gambar 4). Berdasarkan hasil pengamatan nilai COD disemua stasiun berada dibawah baku mutu menurut (Keputusan Menteri Negara Kependudukan dan Lingkungan Hidup No 2 Tahun 1988) yaitu sebesar $100 \mathrm{mg} / \mathrm{L}$. Namun demikian berdasarkan hasil analisis stasiun 3 memiliki perbedaan secara signifikan $(\mathrm{p}<0,05)$ terhadap stasiun 1 dan 2 . Hal ini dapat dikaitkan dengan kondisi fisik perairan stasiun 3 yang merupakan stasiun yang terletak paling luar dekat dengan laut yaitu berada di muara yang disekitarnya terdapat banyak tumbuhan mangrove, di stasiun 3 tersebut merupakan lokasi yang dialiri oleh arus yang membawa material-material lain serta bahan organik dari stasiun 1 dan 2 , sehingga berpotensi mempunyai kandungan COD yang tinggi.

Nilai COD yang tinggi erat kaitannya dengan TSS. Hubungan antara TSS dan COD berbanding lurus yang artinya, semakin tinggi nilai TSS, maka semakin tinggi juga nilai COD (Susilo et al., 2018). Hal ini jelas terjadi pada kandungan COD dan TSS di Stasiun 3. Boerlage (2011), menjelaskan bahwa kandungan COD yang berada di perairan sebagian besar bersumber dari garam anorganik yang terlarut menjadi TDS. Dengan kata lain, TDS mempengaruhi COD secara linear atau semakin besar kandungan TDS maka semakin besar nilai COD. Nilai TDS di Stasiun 3 tertinggi, menyebabkan nilai COD di Stasiun 3 juga menjadi yang paling tinggi.

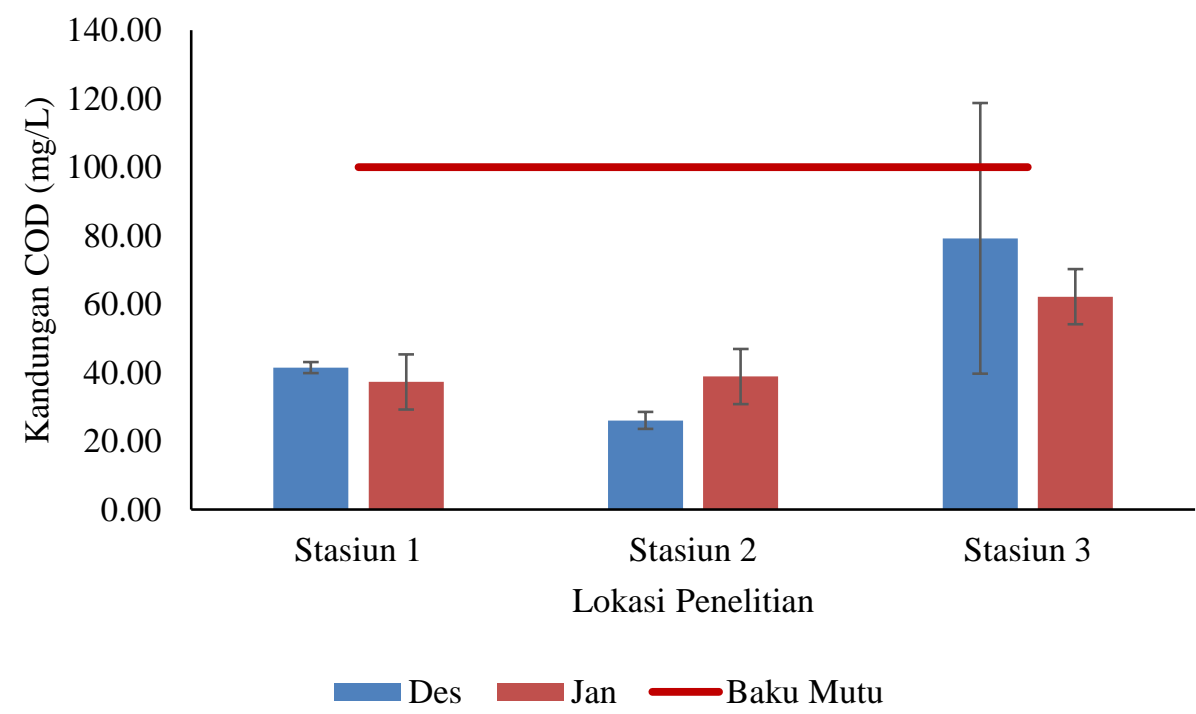

Gambar 4. Kandungan COD di Sungai Silugonggo 
Tabel 1. Pengukuran Parameter Lingkungan

\begin{tabular}{|c|c|c|c|c|c|c|c|c|c|}
\hline \multirow{2}{*}{ Parameter } & \multicolumn{4}{|c|}{ Desember 2019} & \multicolumn{4}{|c|}{ Januari 2020} & \multirow{2}{*}{$\begin{array}{l}\text { Baku } \\
\text { Mutu }\end{array}$} \\
\hline & 1 & 2 & 3 & Rerata & 1 & 2 & 3 & Rerata & \\
\hline Suhu $\left({ }^{\circ} \mathrm{C}\right)$ & $31,6-31,8$ & $32-32,4$ & $33,1-33,2$ & 32,33 & $29,3-32,3$ & $31,6-33$ & $34,2-36,6$ & 32,92 & $\left.25^{* *}\right)$ \\
\hline Alkalinitas (mg/L) & 150 & 141,67 & 158,33 & 150 & 136,67 & 135 & 141,67 & 137,78 & 500 \\
\hline TDS (mg/L) & 622,67 & 1502,33 & 14206,67 & 5443,89 & 136,33 & 418 & 2177 & 910,44 & $5000^{* *)}$ \\
\hline TSS (mg/L) & 25 & 46 & 416 & 162,3 & 16,67 & 52,33 & 182 & 83,67 & 200 \\
\hline Salinitas (ppt) & 0 & 0 & $0-10$ & & 0 & 0 & $0-5$ & & $\left.34^{* * *}\right)$ \\
\hline Ammonia $(\mathrm{mg} / \mathrm{L})$ & 3,18 & 3,68 & 9,82 & 5,56 & 1,3 & 1,85 & 3,58 & 2,35 & 0,02 \\
\hline Nitrit (mg/L) & 0,016 & 0,017 & 0,024 & 0,019 & 0,01 & 0,01 & 0,008 & 0,01 & 0,06 \\
\hline Nitrat (mg/L) & & & & & 4,39 & 4,56 & 8,49 & 5,81 & 1 \\
\hline $\mathrm{pH}$ & $6,9-7,4$ & $7,6-7,9$ & $7,7-7,9$ & 7,6 & $6-7,1$ & $4,9-7$ & $6,4-6,9$ & 6,6 & $\left.7-8,5^{* *}\right)$ \\
\hline $\mathrm{DO}(\mathrm{mg} / \mathrm{L})$ & $1,5-2,1$ & $1,9-2,2$ & $2,9-4,2$ & 2,5 & $4.4-4,8$ & $4-4,3$ & $3,8-4,3$ & 4,3 & $>5 *)$ \\
\hline Kec. Arus (m/s) & $0-0,2$ & $0-0,1$ & $0-0,1$ & 0,07 & $0,16-0,36$ & $0,22-0,67$ & $0,05-0,66$ & 0,33 & $\left.0,25-0,5^{*}\right)$ \\
\hline Kecerahan (m) & $0,17-0,22$ & 0,17 & $0,19-0,23$ & 18,89 & $0,1-0,15$ & $0,13-0,17$ & $0,25-0,7$ & 13,94 & $3 *$ \\
\hline Kedalaman (m) & $1-3$ & 1 & $0,5-3$ & 1,4 & $1-4$ & 1 & $0,5-3$ & 1,4 & $5 *$ \\
\hline Curah Hujan (mm) & 120 & 120 & 120 & 120 & 192 & 192 & 192 & 192 & - \\
\hline
\end{tabular}

Keterangan : *) Keputusan Menteri Negara Kependudukan dan Lingkungan Hidup Nomor 2 Tahun 1988 Tentang Baku Mutu Air Limbah; **) Keputusan Menteri Negara Lingkungan Hidup Nomor 51 Tahun 2004 Tentang Baku Mutu Air Laut untuk Biota Laut; $1=$ Stasiun 1; $2=$ Stasiun 2; $3=$ Stasiun 3

Perbedaan signifikan $(\mathrm{p}<0,05)$ pada Stasiun 3 selain diakibatkan oleh TSS dan TDS, juga diakibatkan oleh tingginya salinitas di Stasiun 3. Secara umum, kandungan COD dari setiap stasiun sangat tinggi, hal ini disebabkan karena adanya kandungan klorin didalam perairan ditandai dengan tingginya salinitas perairan (Sembiring et al., 2012). Terbukti salinitas pada Stasiun 3 tinggi dibandingkan dengan stasiun lainnya, yaitu sebesar 3,33 ppt.

Keberadaan COD dapat berasal dari alam ataupun aktivitas rumah tangga dan industri, perairan yang memiliki nilai COD tinggi tidak diinginkan bagi kepentingan perikanan (Effendi, 2003). Bahan pencemar tersebut berupa limbah organik yang berasal dari industri kacang, tahu, pertanian, limbah ikan yang berada di perairan sungai di Kabupaten Pati (Utomo et al., 2013).

Parameter yang mempengaruhi kandungan bahan organik di lokasi penelitian, meliputi: Suhu, Alkalinitas, TDS, TSS, Salinitas, Ammonia, Nitrit, Nitrat, pH, DO, Kecepatan Arus, Kecerahan, Kedalaman dan Curah Hujan disajikan pada Tabel 1.

\section{KESIMPULAN}

Kandungan Bahan Organik di Perairan Sungai Silugonggo diketahui dari parameter bahan organik adalah sebesar 8,11-11,9 mg/L . Berdasarkan hasil pengukuran parameter bahan organik pada Perairan Sungai Silugonggo meliputi data $\mathrm{BOD}_{5}$ dan COD masih berada di bawah ambang baku mutu yang ditentukan. Hasil tersebut menunjukkan bahwa perairan sungai Silugonggo belum tercemar oleh bahan organik.

\section{DAFTAR PUSTAKA}

Aina, L.C., Rita, E. \& Kaswinarni, F. 2016. Biomonitoring Pencemaran Sungai Silugonggo Kecamatan Juwana Berdasarkan Kandungan Logam Berat $\mathrm{Pb}$ pada Ikan Lundu. Jurnal Bioma, 5(2):1-10.

Atima, W. 2015. BOD dan COD sebagai Parameter Pencemaran Air dan Baku Mutu Air Limbah. Jurnal Biology Science and Education, 4(1):83-93.

Aziza, N. \& Zahruddin, I. 2010. Analisa Pengaruh Intensitas Arus pada Electro Discharge Machine. Jurnal Teknika, 1(1):39-46.

Kabupaten Pati dalam Angka 2015. Profil Kabupaten Pati 2015.

Belladona, M. \& Yanto, H.N. 2014. Perancangan Instalasi Pengolah Air Limbah Domestik Terpadu pada Kawasan Kampung Nelayan di Kota Bengkulu. Jurnal Inersia, 6(1):27-38. 
Boerlage, S. 2011. Measuring Seawater in Seawater Reverse Osmosis. GHD Research, $1-5$.

Effendi, H. 2003. Telaah Kualitas Air : Bagi Pengelolaan Sumberdaya dan Lingkungan Perairan. Penerbit Kanisius. Yogyakarta. 249 hlm.

Hadi, S. 1993. Metodologi Riset. Yayasan Penerbit Fakultas Psikologi UGM. Yogyakarta. 365 hlm.

Hamuna, B., Tanjung., R.H.R., Suwito, \& Maury, H.K. 2018. Konsentrasi Amoniak Nitrat dan Fosfat di Perairan Distrik Depapre Kabupaten Jayapura. Jurnal Enviroscientae, 14(1):8-15

Ismoyo, U., Hendrarto, B. \& Suryanti. 2017. Analisis Bahan Organik dengan Kualitas Tanah terhadap Pukuran Daun Bakau. Jurnal Saintek Perikanan, 12(2):134-148.

Keputusan Menteri Negara Kependudukan dan Lingkungan Hidup Nomor 2 Tahun 1988 Tentang Baku Mutu Air Limbah.

Keputusan Menteri Negara Lingkungan Hidup Nomor 37 Tahun 2003 tentang Metoda Analisis Kualitas Air Permukaan dan Pengambilan Contoh Air Permukaan.

Keputusan Menteri Negara Lingkungan Hidup Nomor 51 Tahun 2004 Tentang Baku Mutu Air Laut untuk Biota Laut.

Maslukah, L., E. Indrayanti, dan A. Rifai. 2014. Sebaran Material Organik Zat Hara oleh Arus Pasang Surut di Muara Sungai Demaan Jepara. Jurnal Ilmu Kelautan 19(4):189-194.

Merriam, S.B. \& Tisdell, E.J. 2015. Qualitative Research: A Guide to Design and Implementation Fourth Edition. Jossey-Bass Publication. San Fransisco. 257 pg.

Paramita, P., Shovitri, M. \& Kuswytasari, N.D. 2012. Biodegradasi Limbah Organik Pasar dengan Menggunakan Mikroorganisme Alami Tangki Septik. Jurnal Sains dan Seni ITS, 1(1):23-26.

Peraturan Pemerintah Republik Indonesia Nomor 38 Tahun 2011 Tentang Sungai.

Rahmawati, Chadijah, S., \& Ilyas, A. 2015. Analisa Penurunan Kadar COD dan BOD Limbah Cair Laboratorium Biokimia UIN Makassar Menggunakan Fly Ash Batubara. Jurnal Al-Kimia, 1(1):64-75.
Rozali, Mubarak, \& Nurrachmi, I. 2016. Patterns of Distribution Total Suspended Solid in River Estuary Kampar Pelalawan. Jurnal Online Mahasiswa UNRI, 3(2):1-10.

Rustam, A., Adi, N.S., Mustikasari, E., Kepel, T.L. \& Kusumaningtyas, M.A. 2018. Karakteristik Sebaran Sedimen dan Laju Sedimentasi Perairan Teluk Banten. Jurnal Segara, 14(3):137-144.

Sari, T.A., Atmodjo, W. \& Zuraida, R. 2014. Studi Bahan Organik Total Sedimen Dasar Laut di Perairan Nabire Teluk Cendrawasih Papua. Jurnal Oseanografi, 3(1):81-86.

Sembiring, S.M.R., Melki, \& Agustriani, F. 2012. Kualitas Perairan Muara Sungsang ditinjau dari Konsentrasi Bahan Organik pada Kondisi Pasang Surut. Maspari Journal, 4(2):238-147.

Septiana, W.C., \& Ardiaria, M. 2016. Efek Pemberian Seduhan Kulit Buah Naga Merah terhadap Kadar MDA Tikus Dislipidemia. Journal of Nutrition College, 5(4):344-352.

Suparjo, M.N. 2009. Kondisi Pencemaran Perairan Sungai Babon Semarang. Jurnal Saintek Perikanan, 4(2) : 38 - 45 .

Supriyantini, E., Nuraini, R.A.T. \& Fadmawati, A.P. 2017. Studi Kandungan Bahan Organik pada Beberapa Muara Sungai Di Kawasan Ekosistem Mangrove, Di Wilayah Pesisir Pantai Utara Kota Semarang, Jawa Tengah. Buletin Oseanografi Marina, 6(1):29-38.

Susilo, F.A.P., Suharto, B. \& Susanawati, L.D. 2018. Pengaruh Variasi Waktu Tinggal Terhadap Kadar BOD dan COD Limbah Tapioka dengan Metode Rotating Biological Contractor. Jurnal Sumber Daya Alam dan Lingkungan. 2(1):21-26.

Utomo, Y., Priyono, B. \& Ngabekti, S.. 2013. Saprobitas Perairan Sungai Juwana Berdasarkan Bioindikator Plankton. Unes Journal of Life Science, 2(1):28-35.

Yuningsih, H.D., Soedarsono, P. \& Anggoro, S. 2014. Hubungan Bahan Organik dengan Produktivitas Perairan pada Kawasan Tutupan Eceng Gondok Perairan Terbuka dan Keramba Jaring Apung di Rawa Pening. Diponegoro Journal of Maquares, 3(1):3743. 